\title{
A Study on Rebound Characteristic of Sealing Ring Used in Solid Rocket Motor
}

Lin JingDong, Huang JinLin, Chen Junhong, Huang Li

Rockwell Automation, College of Automation, Chongqing University, Chongqing 400044, China. E-mail: hj1461707@163.com.

Solid Rocket Motor (SRM) is a key component for the missile and space rocket. Sealing performance is an important index for SRM assembled. It is a necessary condition for study on the sealing performance of SRM to determine the residual stress of sealing ring which is difficult to be obtained by direct detection in engineering practice. This paper derives the quantitative expression of the relationship between residual stress, pressure difference and preload stress and establishes the method of determining residual stress of sealing ring by mechanical analysis. With the help of experiment, verify the correctness and applicability for expression meanwhile, analyze the influence of SRM's types and rubber sealing ring materials on residual stress changed under the effect of pressure difference. Therefore, the method of residual stress determined provides theoretical support to improve the SRM assembly process and lays a foundation for later study on the leakage rate of SRM.

Keywords: Solid rocket motor, Rubber sealing ring, Rebound characteristic, Residual stress

\section{Acknowledgement}

The authors acknowledge the support from Chinese Equipment Manufacturing Unit and the Rockwell Automation of Chongqing University during the course of this study.

\section{References}

[1] GUO, X. VAVILOV, V. (2015). Pulsed Thermographic Evaluation of Disbonds in the Insulation of Solid Rocket Motors Made of Elastomers. In: Polymer Experimenting, Vol. 45, pp.31-40.TTP. Russia.

[2] JAVED, A. CHAKRABORTY, D. (2015). Universal Erosive Burning Model Performance for Solid Rocket Motor Internal Ballistics. In: Aerospace Science and Technology, Vol. 45, pp.150-153.TTP. India.

[3] LIU, W. HE, G. (2014). Storage Life of Silicone Rubber Sealing Ring Used in Solid Rocket Motor. In: Chinese Journal of Aeronautics, Vol. 27, No.6, pp.1469-1476.TTP.China

[4] DE GROH, HENRY C.(2014). Response of elastomer seal materials to solid rocket exhaust emissions, In: Journal of Spacecraft and Rockets, Vol.51. No.1.pp.23-30.TTP.U.S.A.

[5] KUMAR, A.E., MURTHY, V.B., MOHAN, R.C. (2015). Effect of Shim Percentage on Non-Linear Static Behavior of Flex Seal of Rocket Nozzle. In: Materials Today: Proceedings, Vol.2, No.4-5. pp.1427-1434.TTP. India.

[6] SPIRES, D. N. (2012). The Report of the Presidential Commission on the Space Shuttle Challenger Accident[M], In: Progressive Management.Vol.1. TTP.U.SA.

[7] LV, XIAO. WANG, SHIJIE.(2012). Finite element analysis of stress for nozzle zone at channel of pressure vessel. In: Advanced Materials Research, Vol.490-495.pp.2165-2168.TTP.China.

[8] NELSON, N.R., PRASAD, N.S. (2016). Sealing behavior of twin gasketed flange joints. In: International Journal of Pressure Vessels and Piping .Vol.138, pp. 45-50. TTP. India.

[9] DIANY, M., AISSAOUI, H. (2011). Finite element analysis for short term O-ring relaxation. In: Jordan Journal of Mechanical and Industrial Engineering, Vol.5, No.6. pp. 472-482. TTP. Morocco.

[10] WENQUAN SUN, JIAN SHAO, ANRUI HE, PUJUN HAO. (2015). Research on Distribution of Residual Stresses of Cold Rolled Sheet Distorted Area Based on ANSYS. In: Manufacturing Technology, Vol.15, No.2. pp.220-236. TTP. Czech Republic.

[11] STANKOVIČOVÁ, Z., DEKÝŠ, V., NOVÁK, P., SAPIETA, M. (2015). Numerical Simulation of Thermoelastic Stress Analysis. In: Manufacturing Technology, Vol.15, No.5. pp.925-930. TTP. Czech Republic.

[12] ASARE, S. THOMAS, A.G, BUSFIELD, J.J.C.(2009). Cyclic stress relaxation (CSR) of filled rubber and rubber components. In: Rubber Chemistry and Technology,Vol.82, No.1. pp.104-112. TTP. United Kingdom.

[13] ERIKSSON, A., NORDMARK, A. (2014). Non-unique response of Mooney-Rivlin model in bi-axial membrane stress. In: Computers \& Structures, Vol.144. pp. 12-22.TTP.Sweden. 
[14] GREEN, I., ENGLISH, C. (1992). Analysis of Elastomeric O-ring Seals in Compression Using The Finite Element Method[J]. In: Tribology Transaction, Vol. 35, No. 1, pp. 83-88.TTP. U.S.A.

[15] KANNER, L.M., HORGAN, C.O. (2008). On Extension and Torsion of Strain-Stiffening Rubber-Like Elastic Circular Cylinders[J]. In: Journal of Elasticity, Vol.93, No.1. pp.39-61.TTP.U.S.A.

[16] ZADOKS R.I., KOKATAM, D.P.R. (2001). Investigation of the axial stiffness of a bolt using a three-dimensional finite element model. In: Journal of Sound and Vibration, Vol.246, No.2. pp.349-373. TTP.U.S.A.

[17] GB/T16823.1-1997. Stress area and bearing area for threaded fasteners[S]. TTP. China.

[18] DING, X., LU, J. (2016).Theoretical analysis and experiment on gas film temperature in a spiral groove dry gas seal under high speed and pressure. In: International Journal of Heat and Mass Transfer, Vol.96. pp.438450.TTP.China. 